\title{
From the President
}

Dave Fergusson, President

efore I begin my laundry list of topics, I want to recommend the North Carolina Association of School Librarians' 1996 Biennial Conference "Balancing Our Information Future," in High Point, August 7-9. This NCLA section always hosts a wonderful biennial conference and this year's speakers look great. Authors Floyd Cooper and Wil Clay will speak, along with Omni magazine editor Keith Farrell. Pre-conferences address multiculturalism, teaching information skills, and multimedia materials. You may call Karen Perry for information, (910) 886-8187; there is also on-site conference registration and visiting librarians have free access to over 80 exhibitors.

If there is one thing we hear over and over, it's that librarians (or cybrarians) must be at the forefront of the electronic information revolution or we'll perish. One problem: NCLA has had a working listserv running for well over a year now and of the (as I write) 1,672 NCLA members, only 295 are subscribers. SHAME on the rest of you! Order an official NCLA hair shirt today for $\$ 10.95$. NCLA- $L$ is a great, fast, cheap method of communication. More and more Association business and North Carolina information will be posted this way to keep you informed.

Please subscribe now. It is very easy. It's free, and you could become a rich person! (Not for any reason associated with NCLA-L, but it could happen.) To subscribe, send an email message to: listserv@ils.unc.edu and do not enter anything in the subject line. In the body of the message type: SUBSCRIBE NCLA-L YOUR FIRSTNAME LASTNAME. Simple, eh? Then just sit back and wait for the money to come rolling in. If you have questions, please contact John Via at (910) 759-5483 or jev@wfu.edu.

When thinking about the condition of the Association during the past few weeks, my mood has changed elevations regularly. At a recent meeting of the Finance Committee, ably chaired by Teresa McManus, we rediscovered after some discussion, as each Finance Committee seems to do, that the North Carolina Library Association has actually operated with a deficit budget for a number of years now, and that we need to change our method of operation very soon. We are not, like some library associations, in any danger of financial collapse, but unless we make some changes, we will no longer be financially healthy and our effectiveness will be severely limited.

On the up side, John Via put together a successful Legislative Day visit to Washington, D.C., May 6-7, and libraries are hopeful of continued Congressional support. Having often made this trip, I sometimes wonder if we really get much payback for our efforts, but federal library support has actually had great effect in North Carolina where every little bit helps. Six North Carolinians were honored by the ALA Washington Office at their 50th Anniversary Gala and made us proud: Mary Kitt Dunn, Dr. Edward Holley, Dr. Gene Lanier, Dr. Marilyn Miller, the late Dr. Annette Phinazee, and Elinor Swaim.

Because so many of us consider politics a dirty business, we probably are less effective politically than most other urbanized groups. This is the time of year to get involved. Writing your elected officials personalized letters is very effective. Getting in on the ground floor with political newcomers pays off later with interest. Saying good things about politicians to people with whom they come in contact can work, because they feel that you are promoting them even when they are not around. (I know this can be a tough one.) Finally, work with NCLA, the State Library, or your administration or board when the call goes out. Your non-librarian friends will often help out and be very effective.

As 295 of you know by now, the most complex sections of the "Report of the Task Force to Study Governance of NCLA Executive Board" have been posted on NCLA-L for input from you, the members. These sections are topics of discussion at the August 7th Board meeting in High Point, which coincides with the NCASL Conference. Section (1) addresses a possible structure for apportioning voting members on the Board to be most equitable, efficient, and effective. Section (5) recommends a self-study which should include, among other things, possible restructuring of the College and University Section and the Community College Section.

I hope you have taken the time to give your Section or Round Table heads any observations you may have about these issues. And I invite you to send any observations about NCLA to me or any other members of the Executive Board at any time. I know that NCLA is most effective at the grass roots level where so much activity, including excellent educational opportunities, develops, but your input concerning administrative matters is always welcome. 